\title{
A Case of Hypercalcemic Crisis with Resistant Hypertension due to Hyperthyroidism
}

\author{
Hiromichi Suzuki, MD, Kazuoki Kondo, MD and Takao SARUTA, MD
}

\begin{abstract}
A 50-year-old Japanese woman showed hypercalcemic crisis due to hypcrthyroidism, accompanying with high blood pressure. High blood pressure, which did not decrease in spite of normalization of serum calcium and thyroid function, was only reduced after the administration of calcium channel blocker. It may suggest that her high blood pressure related with the vascular changes due to hypercalcemia and hyperthyroidism.
\end{abstract}

Key Words: $\quad$ Hyperthyroidism, Hypercalcemia, High blood pressure, Calcium channel blocker

In thyrotoxic patients, hypercalcemia has been reported to be relatively rare ${ }^{1-3}$. The occurrence of high blood pressure is seen both in patients with hypercalcemia ${ }^{4)}$ and in those with hyperthyroidism $^{5}$, however, concomitance of hypertension and hypercalcemia in patients with hyperthyroidism has received little attention in the literature. The patient described, who presented severe hypercalcemia and hyperthyroidism, continued to have high blood pressure after correction of high serum calcium level and thyroid function. Her blood pressure returned to normal only after the administration of nifedipine, a calcium channel blocker.

\section{CASE REPORT}

A 50-year-old woman with no family history of hypertension or endocrine diseases was referred to Keio University Hospital, on May 1980, because of marked general fatigue. She had been well until February 1980, when she first noticed palpitation on exertion. She consulted a physician, who informed her of her high blood pressure and advised her to take a low sodium diet. During the next 2 months, nausea and vomiting developed and she experienced even at rest. She consulted the physician again, who prescribed some medicines without benefit. Her general condition gradually became worse, and she was referred to the hospital.

She appeared wasted and chronically ill. On physical examination at the time of admission, the temperature was $37.4^{\circ} \mathrm{C}$, pulse 132 and respiration 19. The blood pressure was $174 / 98 \mathrm{mmHg}$. No ophthalmopathy was found. There was mild anemia and no jaundice. No cervical adenopathy was felt and no thyroid struma was palpated. A grade 2 systolic ejection murmur was heard at the apex. The lungs were normal. The liver, spleen and kidneys were not felt. No fine finger tremor was found. The extremities appeared normal and neurological examinations were negative. The urine was normal. The hematocrit was $33.6 \%$ : the white cell count was 4,300 , with the normal differentials. The urea was $23.4 \mathrm{mg}$ per $100 \mathrm{ml}$, the creatinine $1.3 \mathrm{mg}$, and protein $6.6 \mathrm{~g}$ per $100 \mathrm{ml}$. The sodium was $134 \mathrm{mEq}$ per liter, the potassium $3.8 \mathrm{mEq}$, calcium $12 \mathrm{mg}$, and inorganic phosphate $4.8 \mathrm{mg}$. The results of endocrinological examinations are summarized in Table 1. An electrocardiogram showed sinus tachycardia at a rate of 136, with ST-segment changes. An X-ray survey of the bones revealed no abnormal lesion. The upper G.I. series were negative.

After admission, treatment of the hypercalcemia was begun with saline and furosemide as well as monitoring the central venous pressure.

From Department of Internal Medicine, School of Medicine Keio University, Tokyo.

Received for publication December 28, 1982.

Reprint request to: Takao Saruta, MD, Department of Internal Medicine, School of Medicine Keio University, 35 Shinanomachi, Shinjuku-ku, Tokyo, 135, Japan. 
Table 1. The Endocrinological Examinations

\begin{tabular}{|c|c|c|c|c|}
\hline & May 24,1980 & June 21,1980 & Normal $r$ & range \\
\hline $\begin{array}{l}\text { Serum thyroid } \\
\text { stimulating hormone }\end{array}$ & 1.0 & 1.5 & $1.3-7.4$ & $4 \mu \mathrm{g} / \mathrm{ml}$ \\
\hline Serum thyroxine & 38 & 12 & $15-25$ & $\mu \mathrm{g} / \mathrm{m} 1$ \\
\hline $\begin{array}{l}\text { Serum } \\
\text { trilodothyronine }\end{array}$ & 600 & 235 & $81-145$ & $\mu \mathrm{g} / \mathrm{m} 1$ \\
\hline $\begin{array}{l}\text { Serum } \\
\text { parathyroid hormone }\end{array}$ & 0.2 & 0.5 & $0.2-0.8$ & $8 \mathrm{ng} / \mathrm{ml}$ \\
\hline Plasma renin activity & 0.1 & 0.2 & $1.2-2.1$ & $1 \mathrm{ng} / \mathrm{m} 1 / \mathrm{hr}$ \\
\hline $\begin{array}{l}\text { Plasma aldosterone } \\
\text { concentration }\end{array}$ & 29 & 25 & $30-100$ & $\mathrm{pg} / \mathrm{m} 1$ \\
\hline $\begin{array}{l}\text { Urinary catecholamines } \\
\text { Norepinephrine } \\
\text { Epinephrine } \\
\text { Vanillylmandelic Acid }\end{array}$ & $\begin{array}{l}4.6 \\
8.0 \\
3.4\end{array}$ & $\begin{array}{r}8.0 \\
11.2 \\
4.2\end{array}$ & $\begin{array}{c}\text { below } 10 \\
10-90 \\
2-9\end{array}$ & $\begin{array}{l}\mu g / \text { day } \\
\mu g / \text { day } \\
\mu g / \text { day }\end{array}$ \\
\hline
\end{tabular}

The sinus tachycardia and high blood pressure continued despite normalization of the serum calcium. Propranolol (60 mg daily) and methimazole (15 mg daily) were started after the findings of elevated triiodothyronine $(600 \mu \mathrm{g} / \mathrm{ml})$. A combination of captopril (SQ 14225, $75 \mathrm{mg}$ daily), furosemide (80 mg daily) and propranolol (60 $\mathrm{mg}$ daily) did not reduce the elevated blood pressure, but nifedipine (calcium channel blocker, $30 \mathrm{mg}$ daily) decreased the blood pressure to the normal levels.

After the normalization of the blood pressure and thyroid function, exploration for parathyroid lesions was performed. Contrary to expectations, no marked adenoma or hyperplasia was found in the parathyroid. A week after the operation, the patient was discharged. Administration of nifedipine, propranolol and methimazole were continued for the next 2 months, and then the nifedipine was discontinued. The patient's blood pressure has remained in the normal range for more than 2 years.

\section{DISCUSSION}

It is well known that calcium has an important effect on blood pressure ${ }^{6,7)}$. Rapid reduction of the serum calcium concentration is associated with a fall in blood pressure in $\operatorname{man}^{8)}$. Moreover, more than one third of patients with primary hyperparathyroidism and elevated serum calcium levels are hypertensive ${ }^{9,10)}$, and they often become normotensive after parathormone-producing tumors have been removed ${ }^{11)}$. Theoretically, calcium is considered to be able to induce elevation of blood pressure through peripheral vascular construction $^{12)}$ and through the release of pressor substances such as catecholamies and renin ${ }^{13,14)}$.
In the patient described here, the blood pressure remained high after normalization of the serum calcium level. It seems unlikely, therefore, that calcium played any role in the elevation of blood pressure directly. Furthermore, since catecholamies were in the normal range, catecholamines did not appear to be responsible for the elevated blood pressure. The plasma renin activity was low and administration of angiotensin I converting enzyme inhibitor failed to decrease the blood pressure. These data do not suggest that the renin-angiotensin system could play a role in the cause of the hypertension of this patient. The normal renal function of the patient excluded the participation of renal insufficiency in elevating the blood pressure as in other patients with hypercalcemia ${ }^{11)}$. Also the elevated blood pressure of this patient was not reduced after normalization of thyroid function. It seems unlikely, therefore, that the increase in blood pressure in this patient was directly due to either hypercalcemia or hyperthyroidism. The more attracting explanation for the rapid and marked decrease of the blood pressure after the administration of calcium channel blocker is that, even after serum calcium level became normalized, the vasular tissue level of calcium still might be higher than expected. If it will take longer time to reduce the calcium level in the tissues compared to serum calcium level, calcium channel blocker may antagonize calcium in the tissue. This assumption may be supported by our findings that nifedipine exerts an effect on the intracellular calcium ion in dilating blood vessels ${ }^{15}$.

In summary, a rare case with hypercalcemia due to hyperthyroidism accompanying by high blood pressure was reported. The interesting point in this case is that high blood pressure was reduced only by calcium channel blocker.

\section{REFERENCES}

1) Baxter JD and Bondy PK: Hypercalcemia of thyrotoxicosis. Ann Int Med 65: 429, 1966.

2) Parfitt AM and Dent CE: Hyperthyroidism and hypercalcemia. Q J Med 19: 171, 1970.

3) Gordon EL et al: The serum calcium level and its significance in hyperthyroidism: a prospective study. Am J Med Sci 268: 31, 1974.

4) Earll JM, Kurtzman NA, Moser RH: Hypercalcemia and hypertension. Ann Int Med 64: 378, 1966. 
Resistant Hypertension due to Hyperthyroidism

5) Werner SC: Hyperthyroidism. The Thyroid: a fundamental and clinical text. Werner SC and Ingbar SH eds. Maryland, Harper \& Row Publishers, Inc, 4th Ed, 1978, p 591.

6) Rosenbaum JL et al: Effect of sudden blood calcium depletion on phosphorus excretion. Endocrinology 74: 266, 1964.

7) Weidmann $\mathrm{P}$ et al: Blood pressure effects of acute hypercalcemia. Studies in patients with chronic renal failure. Ann Int Med 76: 741, 1972.

8) Shackney $S$ and Hasson J: Precipious fall in serum calcium, hypotension and acute renal failure after intravenous phosphate therapy for hypercalcemia. Ann Int Med 66: 906, 1967.

9) Rosenthal FD and Roy S: Hypertension and hyperparathyroidism. Brit Med J 4: 390, 1972.

10) Scholz DA: Hypertension and hyperparathyroidism. Arch Intern Med 137: 1123, 1977.
11) Cope O: Hyperparathyroidism: Diagnosis and management. Am J Surg 99: 394, 1960.

12) Frohlich ED, Scott JB and Haddy FJ: Effect of renal and forelimb vascular beds. Am J Physiol 203: 583, 1962.

13) Michelakis A: The effect of sodium and calcium on renin release in vitro. Proc Soc Exp Biol Med 137: 833, 1971.

14) Rubin RP: The role of calcium in the release of neurotransmitter substances and hormones. Pharmacol Rev 22: 389, 1970.

15) Kondo et al: Effects of nifedipine, diltiazem and verapamil on the vasoconstriction responses to norepinephrine and potassium ions in the rat mesenteric artery. Arch Int Pharmaca Thera 245: $212,1980$. 